\title{
Correction: H-NS Mediates the Silencing of Laterally Acquired Genes in Bacteria
}

Sacha Lucchini, Gary Rowley, Martin D. Goldberg, Douglas Hurd, Marcus Harrison, Jay C. D. Hinton

doi: 10.1371/journal.ppat.0020081

In PLoS Pathogens, volume 2, issue 8:

In Figure 2, the graphs for parts B and C were transposed. The correct Figure 2 is as follows:

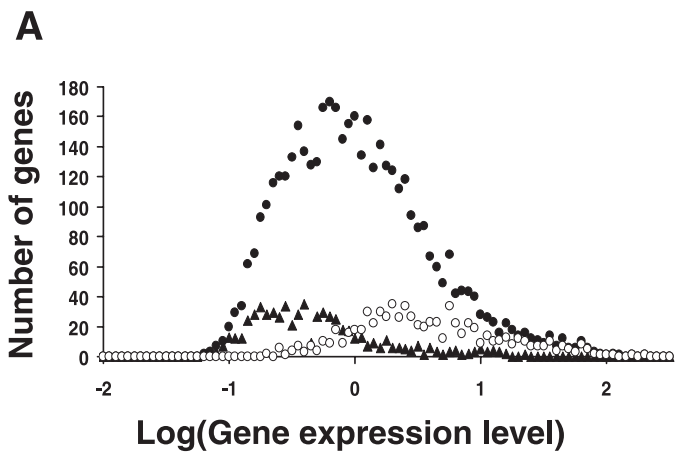

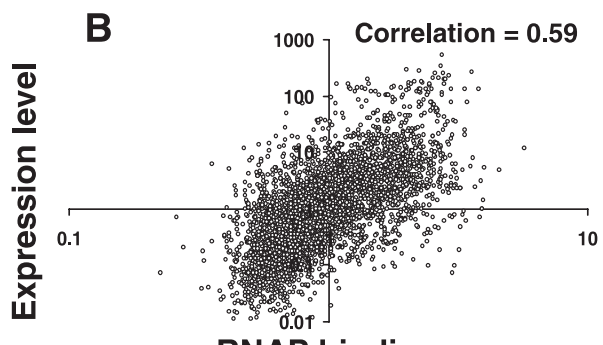

RNAP binding

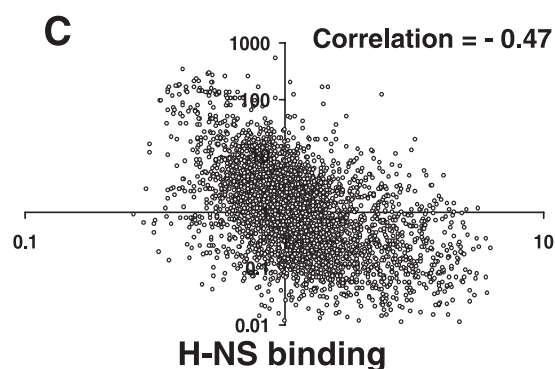

H-NS binding

doi:10.1371/journal.ppat.0030038.g001

This correction note may be found online at doi:10.1371/journal.ppat.0030038.

Published March 30, 2007.

Citation: (2007) Correction: H-NS mediates the silencing of laterally acquired genes in bacteria. PLoS Pathog 3(3): e38. doi:10.1371/ journal.ppat.0030038 